\title{
Die benutting van vraelyste met die oog op meer effektiewe toerusting tydens huweliksvoorbereiding
}

\author{
P J Botha \& T F J Dreyer ${ }^{1}$ \\ Hervormde Teologiese Kollege, Fakulteit Teologie \\ Universiteit van Pretoria
}

\begin{abstract}
The utilization of questionnaires with the intent to make marriage preparation more effective

This study aims to promote the idea that questionnaires used as part of marriage preparation, could be a valuable tool. The article also attempts to identify some themes that should form part of the discussion between the pastor and a couple to prepare them for their marriage. Furthermore, the aim is to assist pastors, especially those in the Nederduitsch Hervormde Kerk van Afrika, utilizing questionnaires during marriage preparation.
\end{abstract}

\section{INLEIDING}

\section{$1.1 \quad$ Inleiding en probleemformulering}

In die meeste kerklike denominasies, maar in die besonder ook in die Nederduitsch Hervormde Kerk van Afrika, word daar van predikante verwag om huwelikskategese of huweliksvoorbereiding met voornemende egpare te doen. Die krisis wat sommige predikante beleef, is dat daar weinig of geen riglyne bestaan vir die uitvoer van hierdie opdrag. Barlow (1999:3) meld die volgende in haar artikel: "Several denominations have included instructions to pastors about the necessity of preparing couples for marriage, but detailed steps to follow are not provided." Indien daar na die Kerkorde van die Nederduitsch Hervormde Kerk van Afrika gekyk word, word selfs die opdrag om huwelikskategese te doen, baie vaag omskryf. Ordinansie 7.2 stel dit soos

\footnotetext{
${ }^{1}$ Die artikel is 'n verwerking van 'n deel van die MA-verhandeling (2006) van ds Peet Botha, ingedien in die Departement Praktiese Teologie, Universiteit van Pretoria. Die verhandeling is getitel "Die ontwerp van vraelyste met die oog op meer effektiewe toerusting tydens huweliksvoorbereiding", en is voorberei onder leiding van prof dr T F J Dreyer, Hoof: Hervormde Teologiese Kollege, Universiteit van Pretoria.
} 


\section{Die benutting van vraelyste}

volg: "Predikante hou met elke voornemende egpaar vooraf huwelikskategese om aan hulle die Bybelse begronding, verwagtinge en verantwoordelikhede van die huwelik te verduidelik." Die "wat" word omskryf, maar nie die "hoe" nie. Die gevolg is dat elke predikant die "kategese" of voorbereiding op 'n lukraak wyse aanpak en na goeddunke inrig.

Die praktyk leer dat daar soms nie eens van huweliksvoorbereiding sprake is nie, en dat dit, indien dit wel gedoen word, dikwels beperk is tot 'n eenmalige gesprek met die voornemende egpaar 'n paar weke voor die huwelikseremonie. In hierdie verband noem Williams (1999:281): "The present study clearly indicates that a single session of marriage preparation has very limited value." Hy verwys dan na die bevindinge van Wright wat meen dat $75 \%$ van die respondente wat sewe of meer sessies voorbereiding deurloop het, sê dat dit hulle huwelik beslis positief beïnvloed het.

Indien daar oor huweliksvoorbereiding gedink en gepraat word, is daar 'n paar vrae wat dadelik opduik:

- Wat wil met huweliksvoorbereiding bereik word?

- Watter vorm moet die ontmoetingsgebeure aanneem?

- Watter sake moet tydens huweliksvoorbereiding aan die orde kom?

- Watter hulpmiddels is daar vir predikante ten opsigte van die hantering van huweliksvoorbereiding?

Egpare vind dit dikwels moeilik om binne die huwelik aan te pas as gevolg van, onder andere, 'n gebrek aan selfkennis, kennis van die huweliksmaat, konflikhanteringsvaardighede en rolverwagtinge binne die huwelik. Miskien is dit tyd dat daar in die Kerk spesifiek aan huweliksvoorbereiding aandag geskenk word.

\subsection{Hipotese}

Daar is vandag al meer "ongesonde" huwelike, waarskynlik deels ook as gevolg van die feit dat daar nie deeglik aandag geskenk word aan huweliksvoorbereiding met voornemende egpare nie. Die gebrekkige toerusting tydens huweliksvoorbereiding is grootliks te wyte aan die feit dat predikante weinig of geen riglyne en/of hulpmiddels het om die voorbereiding mee aan te pak. Deur vraelyste (as hulpmiddel) daar te stel met die oog op meer effektiewe toerusting tydens huweliksvoorbereiding, kan hierdie leemte moontlik gedeeltelik gevul word. Meer effektiewe toerusting tydens huweliksvoorbereiding kan hierdie leemte verder vul en meer "gesonde" huwelike tot gevolg hê, aangesien die egpaar beter toegerus sal wees om krisisse binne die huwelik te hanteer. 
Die daarstel van vraelyste kan die toerusting tydens huweliksvoorbereiding meer effektief maak deurdat dit die gesprek struktureer en terselfdertyd die voornemende egpaar by die toerustingsgebeure betrek. Giblin (1994:149) stel dit duidelik dat die gebruik van vraelyste onontbeerlik is as hy sê: "Most effective of all is the use of a premarital assessment inventory - FOCUS, PREPARE/ENRICH, or PMI - which facilitates couple discussion in specific, concrete ways. The couple mainly talks with each other; no one else talks to them or about them. Even the facilitator simply uses what the couple has said about themselves. Therefore any defensiveness, discussion and curiosity is generally enhanced." In sy proefskrif wys Pretorius (1996:191-192) die leser op die voordele van die gebruik van vraelyste. Ek vul graag Giblin se stelling, hierbo genoem, aan deur Pretorius se stelling dat inligting baie vinniger ingewin kan word met die invul van vraelyste. Hy noem ook dat die pastor die paartjie se groei gedurende sessies kan bepaal. Hy waarsku egter teen die volgende nadele by die gebruik van vraelyste: a) Die paartjie kan die vrae verkeerd verstaan en gevolglik verkeerde inligting weergee; en b) die pastor kan die paartjie etiketteer op grond van inligting wat deur middel van die vraelyste bekom is.

Op grond van navorsing deur Pretorius is die navorser oortuig dat huweliksvoorbereiding wel 'n positiewe invloed uitoefen op die paartjie se verhouding en/of huwelik. Pretorius (1992:143) stel dit soos volg as hy uitspraak lewer oor die korttermyndoeltreffendheid van die huweliksvoorbereidingsprogram: "Uit die eksperimentele evaluering van die huweliksvoorbereidingsprogram blyk dit dat die verloofde pare wat aan die program deelgeneem het oor die korttermyn ('n minimum van drie tot ses weke na voltooiing van die program) beduidend verskil het van die pare wat nie aan die program deelgeneem het nie. Hierdie verbeterde verskil geld vir al die veranderlikes wat geëvalueer is, te wete verhoudingsaanpassing, empatiese begrip, kommunikasievaardighede, positiewe versterking, konflikhanteringsvaardighede en intimiteit."

\subsection{Die doel van hierdie navorsing}

Die oogmerk van hierdie artikel is om:

- Navorsing te doen oor bestaande literatuur oor bogenoemde onderwerp.

- Temas te identifiseer wat tydens huweliksvoorbereiding aan die orde behoort te kom.

- Die benutting van vraelyste tydens huweliksvoorbereiding aan die orde te stel. 
- 'n Kort teologiese perspektief oor die huwelik te bied.

- Om die navorsingsresultate wat opgelewer is bekend te stel aan predikante van die Kerk.

\subsection{Metodologie}

Om in bogenoemde doel te slaag, sal die volgende metode gevolg word:

- Deur middel van ' $n$ literatuurstudie sal die relevante literatuur bestudeer word om op die hoogte te kom van reeds bestaande vraelyste wat moontlik tydens huweliksvoorbereiding aangewend kan word.

- Die temas wat in die literatuurstudie na vore kom sal geëvalueer word, waarna die temas wat tydens huweliksvoorbereiding behoort te figureer aangedui sal word.

- Die resultate sal aan predikante van die Kerk beskikbaar gestel word deur middel van hierdie artikel asook bronverwysings.

\section{LITERATUUROORSIG}

Met die oog op navorsing oor die gebruik van vraelyste tydens huweliksvoorbereiding is literatuursoektogte onderneem om vas te stel watter inligting oor die onderwerp beskikbaar is. Die soektog is elektronies by die Universiteit van Pretoria gedoen en is hoofsaaklik beperk tot die mees resente tydskrifartikels sowel as skripsies, tesisse en proefskrifte.

Tydens die soektog na bestaande vraelyste is gepoog om vraelyste te identifiseer wat die hooftemas tydens huweliksvoorbereiding aanspreek. Die temas wat in hierdie opsig aandag behoort te geniet, is volgens Taylor (1999:40-41) kommunikasie; konflikhantering; rolverdeling; seksualiteit; waardes, geloof en spiritualiteit; kinders; gesin van herkoms; ontspanning; persoonlikheid; finansies; asook huweliksverwagtinge. Alpaslan (1991:19) voeg ook hierby selfbeeld, huwelikskeuse, huweliksmotief, potensiële groeiruimte, beroepsbeoefening, ouerskap asook skoonouers. In sy skripsie bespreek Krömker (1994:A67-A75) 'n interessante perspektief deur ook effektiewe stresbeheer as een van die temas te hanteer. Op grond van die navorsing deur onder andere Lawson (1985) en Taylor (1999) sou ek graag die proses van differensiasie ${ }^{2}$ ook by genoemde lys voeg as tema vir bespreking tydens huweliksvoorbereiding.

\footnotetext{
${ }^{2}$ Differensiasie kan beskryf word as die losmaakproses tussen ouers en kinders wat as voorwaarde dien alvorens die kinders hulleself in die eg laat verbind.
} 
Vir die doel van hierdie ondersoek asook die toepassing van die resultate hiervan, het die navorser dit goed gedink om sekere van bogenoemde temas te kombineer en/of weg te laat.

Vervolgens word die onderskeie temas wat in hierdie navorsing neerslag gaan vind, gelys en gemotiveer aan die hand van bronne waarin die temas aandag geniet. In die volgende afdeling sal daar 'n kort teologiese perspektief oor die huwelik gebied word in so verre as wat dit die onderskeie temas ter sake raak.

\subsection{Kommunikasie en konflikhantering}

Geen verhouding is moontlik sonder kommunikasie nie. As gevolg van die feit dat individue nie altyd eenders dink en doen ten opsigte van sekere sake nie, ontstaan daar soms misverstande wat kan lei tot konflik. Konflikhantering is dus ' $n$ uiters belangrike vaardigheid wat nodig is om ' $n$ verhouding te laat vlot. Louw (1983:79-80) noem 'n paar bedreigende faktore vir huweliksliefde, insluitende gebrek aan kommunikasie. Hy wy dan ook hoofstuk vier van sy boek aan kommunikasie en konflikhantering. Stanley en Trathen (1994:164) maak in hulle artikel die volgende uitspraak: "When partners can communicate well on difficult topics, they are practicing the biblical ideal of oneness that allows both for individuality and an abiding sense of the whole working as a team."

Mol (1996:91-92) maak gebruik van 'n "Ken jou maat"-vraelys om paartjies te help om met mekaar te kommunikeer. Alpaslan (1991:269-289) hanteer ook hierdie temas in sy opnameskedule met betrekking tot huwelikstevredenheid. 'n Deel van sy navorsing sluit ook 'n skedule in waarin paartjies aangemoedig word om hul standpunt ten opsigte van konflikhantering te formuleer (Alpaslan 1991:349-350). Hicks, McWey, Benson en West (2004:106) meld in hulle artikel dat navorsing toon dat paartjies kommunikasie as 'n belangrike aspek van hul verhouding beskou. Stanley en Trathen (1994:164) bespreek in hul artikel hoofsaaklik die PREPprogram, wat ongelukkig nie ter insae was nie. Die skrywers het egter 'n sterk Christelike benadering wat die navorser moontlik kan leiding gee om vrae te ontwerp wat konflikhantering ook op Bybelse beginsels skoei. Jakobus 1:19 word onder andere deur die skrywers aangehaal. Krömker bespreek die saak van konflikhantering in 'n bylae (Krömker 1994:A26-A31). Hy verskaf ook 'n "Inventory of premarital conflict", opgestel deur DH Olson, waarin situasies verduidelik word en die respondente dan uitgenooi word om aan te dui hoe hulle die situasies sou hanteer. 


\section{Die benutting van vraelyste}

Volgens Risch, Riley en Lawler (2003:262) is kommunikasie en konflikhantering onder die mees problematiese sake in die vroeë jare van die huwelik.

\subsection{Gesin van herkoms, skoonouers en differensiasie}

Louw (1986:211-212) noem onder die gedeelte wat handel oor huweliksvoorbereiding 'n paar doelstellings vir voorhuwelikse berading, naamlik "om die konteks waarbinne elkeen groot geword het en tans leef en werk, te begryp en te verwerk." Die verhouding waarin die man en/of vrou ten opsigte van sy/haar eie ouers maar ook aanstaande skoonouers staan, sal die huweliksverhouding in groot mate beïnvloed. Louw (1986:223) bespreek ook die saak van afhanklikheid van die ouerhuis en waarsku dat 'n binding met die ouerhuis tot infantiele gedragspatrone aanleiding kan gee. Hy benadruk die gedagte dat ouerbinding konstruktief deurgesny moet wees. Hy gebruik ook 'n karaktertoets (Louw 1983:162) om die persoonlikheidstruktuur te bepaal en sodoende die mate te peil waarin die ouers 'n rol speel ten opsigte van die karakter van die verloofdes of paartjie.

Alpaslan (1991:309-311) maak in sy proefskrif gebruik van Hudson se indeks, bestaande uit 25 vrae, om die aard en omvang van die kliënt se gesinsverhoudings te meet. Sy opnameskedule bevat ook 'n paar vrae wat aandag skenk aan hierdie tema (Alpaslan 1991:269-289). Krömker (1994:B4) lys sewe vrae wat handel oor gesinne van herkoms en gee ook 'n paar vrae wat handel oor die skoonouers. Risch et al (2003:262) lys die saak van "extended family issues" onder die mees problematiese sake in die vroeë jare van die huwelik. Pretorius (1996:200) bespreek die saak van emosionele volwassenheid. Tog is die navorser van mening dat emosionele volwassenheid hoofsaaklik met differensiasie verband hou. Die hele artikel van Lawson (1985:57-60) skenk ook aandag aan die saak van differensiasie. $\mathrm{Hy}$ bespreek ook die saak van emosionele en psigologiese differensiasie wat moet plaasvind ten opsigte van die partye se gesinne van herkoms. Die saak van differensiasie word ook deur Taylor (1998:54-66) hanteer.

\subsection{Beroepsbeoefening en rolverdeling}

Alpaslan (1991:269-289) se opnameskedule skenk in besonder aandag aan die saak van rolverdeling en verskaf ' $n$ skedule om die aard van rolverdeling in die huwelik te bepaal (Alpaslan 1991:359-361). In hierdie skedule word 35 vrae hanteer wat aandag skenk aan die mees kritiese sake ten opsigte van rolverdeling. Basson (1991:165-166) verwys na die huweliksvoorbereidingsprogram van dr Gertie Pretorius waarin die saak van beroepe bespreek word as 'n belangrike deel van huweliksvoorbereiding. Foutie (1994:107) sê in sy 
gevolgtrekkings oor die evaluering van Alpaslan se voorbereidingsprogram die volgende: "Die huweliksvoor-bereidingsprogram soos ontwikkel deur Alpaslan (1989) skenk wel aandag aan rolverdeling binne die huwelik maar in dié gedeelte van die program word die effek wat beroepsbeoefening op die wyse van rolverdeling in die huwelik sal hê, nie bespreek nie." Hicks et al (2004:108) noem in hul artikel 'n paar van die respondente se response oor rolverdeling en het dus ook in hul navorsing aan hierdie saak aandag geskenk. In die artikel deur Risch et al (2003:262) word rolverwagtinge ook gelys onder problematiese temas wat aandag behoort te geniet.

\subsection{Ouerskap en kinders}

In sy boek noem Van Rensburg (1976:34-35) dat "van die grootste gesinstwiste wat woed en wat man en vrou uitmekaar dryf, gaan oor die kinders. Man en vrou verskil oor die opvoeding van die kinders, oor wat hulle toegelaat of nie toegelaat mag word nie. Die hantering van ons kinders is 'n baie belangrike onderdeel van ons gesinsgeluk en is ook van groot belang vir die vorming van die kinders".

In bylae A van haar skripsie verwys Basson (1991:110-180) na 'n huweliksvoorbereidingsprogram opgestel deur dr Gertie Pretorius. In hierdie program word aandag geskenk aan die tema van kinders in die huwelik (Basson 1991:164-165). Risch et al (2003:262) verskaf, op grond van hulle navorsing, 'n tabel wat die intensiteit van sekere krisisaspekte van die huweliksverhouding aandui. Ten opsigte van die groepie krisisse wat onder kinders hanteer word, word nie minder as agt sake genoem nie. Die vrae in Alpaslan se opnameskedule wat onder ouerskap ressorteer, dui ook daarop dat dit 'n belangrike aspek van huweliksvoorbereiding behoort te wees (vgl Alpaslan 1991:269-289). Die bespreking deur Pretorius (1996:128) dui ook op die belang van hierdie tema.

\subsection{Huweliksverwagting, huwelikskeuse en huweliksmotief}

Die navorsing wat in die artikel van Hicks et al (2004:106-107) bespreek word, dui op die belang van sake soos huweliksverwagtinge, aspirasies en toekomsdrome.

Die appendiks aan die einde van die artikel deur Murray en Murray (2004:358) bevat 'n paar vrae wat aan hierdie tema aandag skenk. Uit De Vries (1996:259-266) se oriënteringsvraelys vir 'n huwelikskeusevoorligtingsprogram blyk dit ook dat hy hierdie tema van belang ag. Alpaslan (1991:339-342) het 'n skedule om die motiewe vir huweliksluiting te bepaal, wat uit 36 vrae bestaan, vir hierdie doel ontwerp. Hy beskou dus ook hierdie saak as belangrik sover dit huweliksvoorbereiding aangaan. Krömker (1994:B6) verskaf 'n paar vrae oor die waardes en/of motiewe vir 


\title{
Die benutting van vraelyste
}

huweliksluiting en bevestig die belang van hierdie tema. Foutie (1994:35-36) wy in sy navorsing ook 'n gedeelte aan hierdie tema deur 'n paar motiewe vir huweliksluiting te bespreek. Louw (1983:14-20) gee in sy boek 'n paar gedagtes weer oor die eiesoortige nood van die hedendaagse huwelik. In hierdie gedeelte word 'n paar verkeerde motiewe vir die huwelik genoem. In die daaropvolgende hoofstuk bespreek hy karaktereienskappe van 'n volwasse huwelik, waarin 'n paar sake genoem word wat aansluit by hierdie tema.

\subsection{Seksualiteit}

In Alpaslan se opnameskedule word heel party vrae oor hierdie tema gevra, wat die belang daarvan aandui (vgl Alpaslan 1991:269-289). Risch et al (2003:262) gee in hulle artikel ook aan hierdie saak aandag. Die artikel van Hicks et al (2004:104-105) toon ook aan dat hul navorsing aan hierdie tema aandag gegee het. Krömker (1994:B5) se vrae in sy bylae wat handel oor seksualiteit, het 'n sterk Christelike onderbou en lig ook die belang van die tema uit. In beide sy boeke wy Louw 'n hoofstuk aan huweliksliefde (Louw 1983:43-79) en pastoraat en seksualiteit (Louw 1986:141-166).

\subsection{Persoonlikheid en selfbeeld}

Louw (1986:211) noem as deel van die doelstellings vir huweliksberading:

\begin{abstract}
Om elke individu te help om eerlik na homself te kyk en 'n evaluering te maak van sy geskiktheid vir 'n huwelik. Belangrik is dus: selfinsig in die eie persoonlikheidstruktuur en graad van geloofsvolwassenheid ... Om die paartjie te help om 'n evaluering van die maat se persoonlikheidstruktuur en waardesisteem te maak ten einde vas te stel wat die moontlikheid van 'n volwasse huwelik is.
\end{abstract}

Laasgenoemde aanhaling dien reeds ook as motivering vir die volgende tema. Louw (1983:97) stel dit ook dat “... iemand wat onseker is van homself en twyfel aan die sin en doel van sy lewe, beswaarlik in 'n verhouding kan tree wat daarop gemik is om positief aanvullend te wees. Wie onseker is oor sy eie identiteit kan moeilik 'n bydrae lewer tot die opbou van 'n wedersydse verhouding."

Louw (1986:23-24) merk in 'n ander boek van hom op:

As gevolg van 'n onvoldoende eie identifikasie kan dit gebeur dat jy jouself met die maat identifiseer en sodoende 'n oordrewe afhanklikheidsgevoel ontwikkel. Aan die ander kant kan dit weer 
gebeur dat jy so die maat met jouself identifiseer, dat jy nie genoeg ruimte vir sy/haar eie persoonlikheidsontplooiing laat nie. Die gevolg is dat jou maat in jou teenwoordigheid versmoor word. 'n Lae selfprofiel en 'n verlies aan eiewaarde (swak identiteitsgevoel) kan tot onjuiste ideale vir die huwelik aanleiding gee.

Verskeie navorsers maak gebruik van die temperamentsvraelys, waaronder Alpaslan (1991:323-330), De Vries (1998:294-301), Mol (1996:20-27) asook Foutie (1994:69) in sy bespreking van Alpaslan se huweliksvoorbereidingsprogram. Die navorser maak egter gebruik van 'n gewysigde vraelys en interpretasie wat reeds met groot vrug in die praktyk gebruik is tydens berading met egpare wat huweliksprobleme ondervind.

In die proefskrif van De Vries (1998:267-275) word gebruik maak van Rebecca Cutter se werk, wat handel oor linker- en regterbreindominansie en die invloed daarvan op ' $n$ persoon se persoonlikheid. Die selfbeeldindeks van Hudson wat deur Alpaslan (1991:318-321) gebruik word, bevat 25 vrae wat spesifiek oor hierdie tema handel. De Vries (1998:283-294) maak gebruik van 'n selfkonsepinventaris, opgestel deur prof J D Very. Alpaslan (1991:269-289) se opnameskedule bevat ook verskeie vrae wat handel oor selfbeeld en persoonlikheid.

\subsection{Waardes, geloof en spiritualiteit}

'n Gesonde verhouding met jouself en jou huweliksmaat spruit voort uit 'n gesonde verhouding met God. Sonder 'n gesonde vertikale verhouding sal die horisontale verhoudings nie vlot nie. Krömker (1994:B6) se bylae bevat 'n paar vrae oor die waardes ten opsigte van die huwelik.

Onder die opskrif "Liefdesgemeenskap het waardes" bespreek Pretorius (1996:147) 'n paar basiese aspekte van Christelike waardes wat in die huwelik tuishoort. Dit sluit in liefde, vergifnis en geluk. Hy verwys ook na Worthington wat meen dat die sukses van die huwelik afhang van die gemeenskaplike of nie-gemeenskaplike waardes van die paartjie. Hieronder noem hy toegewydheid, getrouheid, tyd alleen, tyd saam en vergifnis.

Louw (1986:99-116) se hoofstuk oor huwelikspastoraat as oorwinningsorg lê sterk klem op die Bybelse beginsel van versoening en vergifnis wat voortspruit uit die liefde van God vir die mens en die daaropvolgende versoening met die mens deur die dood van Jesus Christus. Hierdie waardes is uiters belangrik vir die bou van gesonde huweliksverhoudings.

In sy opnameskedule gee Alpaslan (1991:269-289) ook aandag aan hierdie tema, alhoewel daar nie oor spiritualiteit nie, maar eerder oor godsdiens gepraat word. Pretorius (1996:205) bespreek die probleem van 


\section{Die benutting van vraelyste}

huwelike oor kultuur- en geloofsgrense heen en meen dat dit gaan toeneem.

Dit gebeur al meer dat mense oor kleur-, kultuur- en godsdiensgrense heen trou. Daarom is dit uiters noodsaaklik om tydens huweliksvoorbereiding aan hierdie saak aandag te skenk.

Verskeie artikels skenk aandag aan byna al die temas hierbo genoem, waaronder die volgende bronne genoem kan word: Die artikel van Williams et al (1999:277) verskaf 'n tabel met die deelnemers aan 'n huweliks-

voorbereidingsprogram se opinies oor die waarde van verskeie onderwerpe of temas waaraan aandag geskenk is. 'n Soortgelyke tabel word verskaf in 'n ander artikel deur Williams (1992:509). In 'n artikel deur Sullivan en Anderson (2002:394) word agt temas gelys, wat die meeste temas wat in hierdie werk opgeneem word, insluit.

\section{3. 'N KORT TEOLOGIESE PERSPEKTIEF OOR DIE HUWELIK IN SOVERRE AS WAT BOGENOEMDE TEMAS TER SAKE IS}

\subsection{Kommunikasie en konflikhantering}

Word daar in die Heilige Skrif gesoek na gedeeltes wat kommunikasie en konflikhantering aanspreek en riglyne verskaf, kan die volgende 'n teologiese perspektief op hierdie tema bied:

- In Genesis 2:24-25 word gesê dat man en vrou een sal word. Alhoewel hulle kaal was, was hulle nie skaam vir mekaar nie. Dit gaan dus hier oor die huwelik wat 'n ruimte moet wees waar geborgenheid en veiligheid te vind is. Daar moet wedersydse vertroue, aanvaarding, hulp, begrip en respek vir mekaar wees. Man en vrou het 'n natuurlike behoefte aan aanvaarding en 'n natuurlike vrees vir verwerping. 'n Verhouding waarin beide partye veilig voel, is slegs moontlik indien genoegsame kommunikasie- en konflikhanterings-vaardighede teenwoordig is.

- In Efesiërs 4:25-26 word die gelowiges gemaan om die waarheid onder mekaar te praat en nie 'n dag kwaad af te sluit nie.

- In Spreuke 12:16 en 18 word die leser dit op die hart gedruk om versigtig na te dink voordat daar gepraat word. Verder word gestel dat wyse mense se woorde genesing bring. 
- Matteus 6:14 volg op die gebed wat Jesus, volgens die beskrywing van Matteus, gebid het. In hierdie vers word dit duidelik gestel dat 'n mens nie vergifnis van God kan verwag indien hy/sy nie bereid is om ander te vergewe wat teenoor hom/haar oortree het nie.

- Jakobus 1:12 en 20 stel dit dat ' $n$ mens in versoeking standvastig moet bly en nie moet kwaad word nie.

Al bogenoemde gedeeltes bied dus ' $n$ teologiese perspektief op die feit dat kommunikasie en konflikhantering belangrike temas is wat tydens huweliksvoorbereiding aandag behoort te geniet.

\subsection{Gesin van herkoms, skoonouers en differensiasie}

Die duidelikste teks in die Bybel in verband met hierdie tema, is sekerlik Genesis 2:24. Die klem val hier op differensiasie. 'n Man sal sy pa en ma verlaat, sy vrou aankleef en hulle sal een word. Die hele gedagte van "leaving en cleaving", wat na vore kom in Taylor (1998:54-66), is hier van toepassing.

Louw (1986:211-212) noem onder die gedeelte wat handel oor huweliksvoorbereiding ' $n$ paar doelstellings vir voorhuwelikse berading, naamlik "om die konteks waarbinne elkeen groot geword het en tans leef en werk, te begryp en te verwerk." Die verhouding waarin die man en/of vrou ten opsigte van sy/haar eie ouers maar ook aanstaande skoonouers staan, sal die huweliksverhouding in groot mate beïnvloed. Louw (1986:223) bespreek ook die saak van afhanklikheid van die ouerhuis en waarsku dat ' $n$ binding met die ouerhuis tot infantiele gedragspatrone aanleiding kan gee. Hy benadruk die gedagte dat ouerbinding konstruktief deurgesny moet wees. Hy gebruik ook 'n karaktertoets (Louw 1983:162) om die persoonlikheidstruktuur te bepaal en sodoende die mate te peil waarin die ouers ' $n$ rol speel ten opsigte van die karakter van die verloofdes of paartjie.

\subsection{Beroepsbeoefening en rolverdeling}

In Efesiërs 5:21-24 en Kolosense 3:18-19 word die gedagte geopper dat die vrou onderdanig moet wees aan die man en dat die man die vrou moet liefhê. Efesiërs 5:21 voeg egter ' $n$ belangrike gedagte by deur te eis dat man en vrou, uit eerbied vir Christus, aan mekaar onderdanig moet wees. Die gedagte dat die man die baas en die vrou die slaaf is, is lank nie meer realisties nie. Die klem het verskuif van outoritêre huwelike na vennootskapshuwelike. Louw (1986:13-15) bespreek hierdie saak en stel dit soos volg: "In die plek van die tipe het die rolfunksie gekom. Man en vrou word nie met 'n vooropgesette idee belas nie, maar as gelykwaardige persone gesien, elk met ' $n$ unieke 


\section{Die benutting van vraelyste}

rolfunksie met die oog op 'n reële huweliksverhouding." Galasiers 3:28 stel dit duidelik dat daar nie onderskeid is tussen Jood of Griek, slaaf of vry, man of vrou nie, maar dat die gelowiges in Christus Jesus almal één is. Die klem val dus op gelykwaardigheid voor die aangesig van God.

In Titus 2:1-8 word 'n paar eienskappe genoem wat gelowige mans en vroue behoort te openbaar. Ten opsigte van die mans kan die volgende eienskappe vermeld word: Hulle moet nugter wees, eerbaar, verstandig gesond en vas in geloof, liefde en volharding. Verder moet hulle 'n voorbeeld stel van goeie werk, suiwerheid in die leer en waardigheid in gedrag. Ten opsigte van die vroue word ook 'n paar eienskappe genoem, naamlik: Hulle moenie kwaad praat of aan drank verslaaf wees nie. Hulle moet goeie raad kan gee, sodat hulle die jonger vroue kan leer om liefdevol teenoor hulle mans en kinders te wees, verstandig en kuis, goeie huisvrouens, onderdanig aan hulle mans.

\subsection{Ouerskap en kinders}

Daar is verskeie tekste in die boek Spreuke wat verwys na ouerskap en kinders. Die volgende tekste handel almal oor die rol en belang van beide vader en moeder se betrokkenheid ten opsigte van die opvoeding van hulle kinders: Spr 6:20; 17:25; 19:26; 20:20; 23:22 en 25; 28:24 asook 30:11 en 17. In Efesiërs 6:4 en 1 Tessalonisense 2:4 word ouers opgeroep om hulle kinders met tug en vermaning op te voed. Dit moet egter altyd in liefde geskied. Kolosense 3:21 druk die leser dit op die hart dat ouers nie hulle kinders moet vertoorn en terg sodat hulle opstandig word nie.

In sy boek noem Van Rensburg (1976:34-35) dat "van die grootste gesinstwiste wat woed en wat man en vrou uitmekaar dryf, gaan oor die kinders. Man en vrou verskil oor die opvoeding van die kinders, oor wat hulle toegelaat of nie toegelaat mag word nie. Die hantering van ons kinders is 'n baie belangrike onderdeel van ons gesinsgeluk en is ook van groot belang vir die vorming van die kinders."

Van Rensburg (1976:75-76) som die doel van opvoeding van die kinders deur die ouers soos volg op:

A) Gesonde vroomheid, naamlik trou ten opsigte van die Here God en sy opdragte met klem op vrees (eerbied en ontsag) vir die Here asook onvoorwaardelike godsvertroue (vgl Spr 1:7; Job 28:28; Ps 111:10; Jer 17:5-8; Ps 23, 61, 91, 121, 123, 124, 125, 128; Spr 3:5-7; 16:20; 20:22 en 28:25).

B) Liefdevolle inagneming van die medemens met eerbiediging van die owerheid of koning (vgl Spr 24:21; 16:14; 19:12; 20:2; Klaagl 4:22; en Pred 10:20). 
C) Ouers moet deur die kinders geëer word. Hieraan is ook beloftes van seën en bedreigings met vloek verbonde (vgl Eks 20:12; Deut 5:16; Spr 1:8; 23:22 en 25; 28:24; Mal 1:6; Ps 35:14; en Jer 3:1-9).

D) Die oues van dae moet met eerbied bejeën word.

E) Naasteliefde in die algemeen (vgl Lev 19:18; Spr 20:22; en 25:21).

\subsection{Huweliksverwagting, huwelikskeuse en huweliksmotief}

Die belangrikste tekste uit die Skrif in hierdie verband is sekerlik dié uit Genesis 2:18, 20 en 23. Die klem val op die feit dat dit nie goed was dat die mens alleen was nie. Hy kon onder al die skepsels nie een kry wat by hom pas nie. Gevolglik skep God vir hom (Adam) 'n gelyke, een soos hy wat by hom pas. Hierdie tekste vertel iets van huwelikskeuse en -motief. Verder kry die mens die opdrag om te vermeerder en om oor die aarde te versprei. Aanvanklik was een van die grootse motiewe vir die huwelik die voortbring van 'n nageslag.

Johannes 3:16 stel dat God sy seun uit liefde na die wêreld toe stuur. Alles wat God vir en met die mens doen, spruit voort uit sy liefde vir die mens. Net so is liefde 'n sentrale motief vir die huwelik. Verder stel Spreuke 18:22 en 19:14 dat 'n vrou 'n geskenk van die Here is en vergelyk word met die goedheid van die Here. Die hele boek Hooglied van Salomo beskryf en besing die liefde wat daar is en kan wees tussen huweliksmaats. Dit vertel van liefde, aangetrokkenheid en selfs hartstog.

\subsection{Seksualiteit}

In die skeppingsverhaal (Gen 2:25) word gestel dat man en vrou naak maar tog nie skaam vir mekaar was nie. Dit is duidelik dat dit slegs moontlik is in 'n verhouding waarin daar intimiteit ontstaan het. Hierdie intimiteit ontwikkel verder tot eenwording (Gen 2:24). Verder word die vrou aan die man gegee as gelyke en as een wat kan help. Hier is dus ook sprake van psigiese intimiteit.

In 1 Korintiërs 7:3-5 word gestel dat die vrou nie oor haar eie liggaam beskik nie, maar die man. Net so beskik die man nie oor sy eie liggaam nie, maar die vrou. Verder moet man en vrou mekaar nie omgang weier nie sodat Satan die partye nie weens gebrek aan selfbeheersing mislei nie. In 1 Korintiërs 7:36-37 word jongmense gewaarsku dat indien die begeerte na seksuele intimiteit te sterk word, die partye eerder moet trou.

In Spreuke 5:15-20 word die pragtige beeldspraak gebruik van 'n bokkie wat uit ' $n$ fontein drink. Die leser word opgeroep om binne die monogame huwelik bedwelm te word deur die liefkosings van sy eie vrou. 


\section{Die benutting van vraelyste}

\subsection{Persoonlikheid en selfbeeld}

In Genesis 2:18 kom die gedagte van "mekaar tot hulp wees" duidelik na vore. Indien man en vrou mekaar enigsins tot hulp wil wees, sal hulle eerstens selfkennis moet hê. Beide man en vrou sal dus hulle eie selfbeeld en persoonlikheid, maar ook dié van die maat, goed met ken. Steenkamp en Van der Merwe (1982:1) noem reeds op die eerste bladsy van hulle boek dat een ding wat in huwelike ontbreek, begrip is vir mekaar, wat weer kan lei tot misverstande en groot smart kan meebring.

Man en vrou is totaal verskillend geskep. Dit is juis hierdie andersheid wat maak dat hulle mekaar binne die huweliksverhouding kan aanvul.

\subsection{Waardes, geloof en spiritualiteit}

'n Gesonde verhouding met jouself en jou huweliksmaat spruit voort uit 'n gesonde verhouding met God. Sonder 'n gesonde vertikale verhouding sal die horisontale verhoudings nie vlot nie.

Hosea 1-3:5 is 'n goeie voorbeeld van hoe die volk Israel se verhouding met God skade gely het. Hosea se huwelik met 'n prostituut beeld dan die verhouding tussen God en sy volk uit. Die waardes wat na vore kom in die gedeelte en die wyse waarop God die verhouding met sy volk herstel, is na my mening ook van toepassing binne die huwelik tussen man en vrou. Hosea 2:18-19 stel dit soos volg: "Ek gaan jou my bruid maak vir altyd. Ek gaan jou aan My bind deur my weldade en my goeie sorg, deur my liefde en my ontferming. Ek gaan jou aan My bind deur my onverbreekbare trou sodat jy aan My, die Here, toegewy sal wees."

In Openbaring 21:2 en 9 tref 'n mens die gedagte aan dat die kerk die bruid van Christus is. Die beeld van die huwelik word ook in Efesiërs 5:21-32 toegepas op Christus en die kerk. Geloof en spiritualiteit is dus ook belangrike temas wat tydens huweliksvoorbereiding aan die orde moet kom. Louw (1983:43-79) lê besondere klem op die huwelik en die saak van die beeld van God. Beide man en vrou is na die beeld van God geskape en is in hulle huwelik ook verteenwoordigers van God. Verder word daar ook 'n vergelyking getref tussen huwelikstrou en God se verbondstrou.

\section{GEVOLGTREKKING}

\subsection{Temas}

In die lig van die navorsing hierbo bespreek blyk dit duidelik dat daar in die eerste plek 'n paar kern sake is wat tydens die gesprek met die oog op huweliksvoorbereiding aan die orde behoort te kom. Die navorsing wat reeds op hierdie gebied gedoen is, en hierbo uiteengesit is, toon duidelik watter 
temas van belang is. In die kort teologiese perspektief wat gebied word, is daar ook duidelik aangetoon dat die temas ook op verskeie plekke in die Bybel voorkom en 'n riglyn in hierdie verband bied.

\subsection{Vraelyste}

Op grond van bogenoemde navorsing is die skrywer oortuig daarvan dat die benutting van vraelyste wel kan lei tot effektiewer toerusting tydens huweliksvoorbereiding. Die leser word in hierdie opsig verwys na die skripsie deur Botha (2005) waarin die volledige vraelyste opgeneem is en beskikbaar is vir predikante. Indien die vraelyste daarin benut word, kan dit deur die hedendaagse pastor as 'n werkbare dokument gebruik word en in die praktyk aangewend kan word met die oog op effektiewer huweliksvoorbereiding met paartjies wat op die punt staan om in die huwelik te tree.

\section{Literatuurverwysings}

Alpaslan, A H 1991. Huweliksbegeleiding deur middel van die aanvullende gebruik van primêre metodes van maatskaplike werk. D Phil-proefskrif, Universiteit van Pretoria.

Basson, E H 1991. Die doeltreffendheid van psigotegnologie in huweliksvoorbereiding. MA-skripsie, Randse Afrikaanse Universiteit.

Barlow, J L 1999. A new model for premarital counseling within the church. Pastoral Psychology 48(1), 3-9.

Botha, P J 2005. Die ontwerp van vraelyste met die oog op meer effektiewe toerusting tydens huweliksvoorbereiding. MA-skripsie, Universiteit van Pretoria.

De Vries, H 1998. Die ontwerp van 'n voorligtingsprogram om jeugdiges te begelei in die keuse van 'n huweliksmaat. D-Ed proefskrif, Universiteit van Suid-Afrika.

Die Bybel - Nuwe Afrikaanse Vertaling. 1984. Kaapstad: Die Bybelgenootskap van Suid-Afrika.

Foutie, V W R 1994. Huweliksvoorbereiding: 'n Programevaluering. MA-skripsie, Universiteit van Port Elizabeth.

Giblin, P 1994. Premarital preparation: Three approaches. Pastoral Psychology 42(3) 147-161.

Hicks, M W, McWey L M, Benson K E \& West S H 2004. Using what premarital couples already know to inform marriage education: Integration of a Gottman Model Perspective. Contemporary Family Therapy 26(1) 97-113.

Krömker, S 1994. Preparation for marriage: The evaluation of a premarital programme for Trinity Baptist Church. MA Dissertation, University of Port Elizabeth.

Lawson, D M 1985. Differentiation in premarital preparation. Journal of psychology and Christianity 4(3) 56-63.

Louw, D J 1983. Die volwasse huwelik. Pretoria: Sigma-Pers.

Louw, D J 1986. Versoening in die huwelik. Pretoria: Sigma-Pers.

Mol, A 1996. Kom ons wen saam. 2e uitgawe. Kaapstad: Struik. 


\section{Die benutting van vraelyste}

Murray, C E \& Murray, T L 2004. Solution-focused premarital counselling: Helping couples build a vision for their marriage. Journal of Marital and Family Therapy 30(3) 349-358.

Nederduitsch Hervormde Kerk van Afrika 2004. Kerkorde. Pretoria: Sentik.

Pretorius, H G, Van Wyk, J D \& Schepers, J M 1992. Die evaluering van 'n huweliksvoorbereidingsprogram. South-African Journal of Psychology 22(3) 140-146.

Pretorius, W A 1996. Huweliksvoorbereiding: 'n Teologiese praktykteorie. DThproefskrif, Universiteit van Suid-Afrika.

Risch, G S, Riley, M G \& Lawler, M G 2003. Problematic issues in the early years of marriage: Content for premarital education. Journal of Psychology and Theology 31(3), 253-269.

Stanley, S M \& Trathen, D W 1994. Christian PREP: An empirically based model for marital and premarital intervention. Journal of Psychology and Christianity 13(2), 158-164.

Steenkamp, P L \& Van der Merwe, J C 1982. Huweliksgeluk. Pretoria: NHW-Pers. Taylor, C W 1999. Premarital guidance. Minneapolis, MN: Fortress.

Van Rensburg, W C J 1976. En as ek die liefde nie het nie. Kaapstad: HAUM.

Williams, L M et al 1999. An empirical approach to designing marriage preparation programs. The American Journal of Family Therapy 27, 271-283. 